DOI:

Роман Баландюк, кандидат педагогічних наук, вчитель історії Житомирської гімназії № 23

\title{
МЕТОДИЧНІ РЕКОМЕНДАЦЇ̈ ЩОДО НАВЧАННЯ “ПІДПРИСМЛИВОСТІ ТА ФІНАНСОВОЇ ГРАМОТНОСТІ” НА УРОКАХ ІСТОРІЇ УКРАЇНИ
}

У статті розглядаються питання, щео стосуються проблем методики навчання історії України. Визначено комплекс методичних рекомендацій, щуо сприятимуть активному навчанню “підприємливості та фінансової грамотності". Дієвим механізмом втілення “підприємливості та фінансової грамотності” є використання компетентнісного, діяльнісного та особистісно орієнтованого підходів. Встановлено, изо шкільний курс “Історія Украӥни” має величезний потенціал у реалізації ключової компетентності “ініціативність та підприємливість”.

Ключові слова: компетентність; історія України; діяльнісний підхід; фінансова грамотність; навчання підприємливості.

Jim. 6.

Roman Balandyuk, Ph.D.(Pedagogy), Teacher of History Zhytomyr Gymnasium №23

\section{METHODICAL RECOMMENDATIONS OFTEACHING "AN INITIATIVE AND FINANCIAL LITERACY" WITHIN THE LESSONS OF HISTORY OF UKRAINE}

The article deals with the problem of methods of teaching History of Ukraine based on the investigation of home and world experience on the issue. In this article such methods as analysis, synthesis, comparison and generalization have been used. Not many of modern pupils feel comfortable in questions of practical using of economic material within the History school course. Many scholars such as K. Bakhanov, A. Nikora, T. Smagina investigated methods of teaching Social Science. E. Bobinska, G. Nazarenko, M. Tovkalo and others explored the process of teaching entrepreneurial competence at school. But the current period is characterized by the lack of guidance literature on teaching "initiative and financial literacy" within the school course of History of Ukraine. That's why the aim of the article is to generalize the available scientific and pedagogical experience in forming entrepreneurial competence and suggest modern recommendations in teaching "initiative and financial literacy" by means of the school course of History of Ukraine.

The research proves the school course of History of Ukraine is multipurpose and has a great potential in realization of integrated meaningful line "initiative and financial literacy". The author gives such recommendations to the content of the school course of History of Ukraine, as: using the potential of the content from the curriculum of History of Ukraine; emphasizing how someone became successful and how others failed in their business in the span of historical period; including emotions in the economic material of the course; combining educational material with the real world of schoolchildren, their interests and possibilities. There are other recommendations to the development of comprehension and attitude to "initiative and financial literacy", as: including the desire and possibilities among teachers when it goes to built "initiative and financial literacy"; constructing the teaching process in such a way, which helps to create attitude and comprehension among schoolchildren. It is proposed recommendations to activities when it comes to forming entrepreneurial competence, as: including the experience of schoolchildren, active using of interactive methods of teaching, different forms of cooperation, realizing "initiative and financial literacy" both in the theoretical and practical levels.

Keywords: competence; History of Ukraine; an activity approach; financial literacy; teaching of initiative.

П остановка проблеми. Фінансова безграмотність, $з$ одного боку, $є$ однією $з$ причин тяжкого життя більшості населення України. Знання та навички 3 галузі фінансів 3 кожним днем стають усе більше затребуваними для людей, які живуть в сучасному цивілізованому світі. Інтерес до фінансових знань проявляють люди всіляких професій і самого різного достатку. Тому, користуючись можливостями шкільного курсу "Історія України”, можна дослідити як навчити молоде покоління бути грамотними у питаннях підприємливості та фінансів.

3 іншого боку, аналіз чинної навчальної програми з історії, а також сучасної практики навчання історії в школі свідчать про те, що методичні рекомендації щодо навчання “підприємливості та фінансової грамотності" поки не $\epsilon$ предметом окремого розгляду ані вчителів, ані методистів, що призводить до зниження ефективності навчально-виховного потенціалу історії України як навчального предмета. 


\section{МЕТОДИЧНІ РЕКОМЕНДАЦІЇ ЩОДОНАВЧАННЯ "ПІДПРИЄМЛИВОСТІ ТА ФІНАНСОВОЇ ГРАМОТНОСТІ"НА УРОКАХ ІСТОРІЇ УКРӒ̈НИ}

Отже, об'єктивні потреби розвитку підприємливості та фінансової грамотності, практика навчання історії в загальноосвітній школі, а також недостатня розробленість цієї проблеми обумовили вибір та актуальність теми.

Аналіз останніх досліджень. Проблемам методики навчання суспільствознавчих дисциплін присвячені праці таких дослідників, як: К. Баханов, А. Нікора, Т. Смагіна та ін. Процесом навчання підприємницької компетентності у шкільній практиці присвячені напрацювання Є. Бобінської, Г. Назаренко, М. Товкало та інших. Проте питання реалізації інтегрованої змістової лінії “підприємливість та фінансова грамотність” висвітлено недостатньо, щоб іiі втілювати практично на уроках історії.

Метою статті $\epsilon$ узагальнення наявного науково-методичного досвіду 3 визначеної проблеми та бажання запропонувати сучасні рекомендації щодо навчання “підприємливості та фінансової грамотності” на уроках історії України. Основні завдання полягають у тому, щоб проаналізувати науково-методичну літературу 3 теми та розробити методичні рекомендації щодо навчання “підприємливості та фінансової грамотності" за допомогою шкільного курсу історії України.

Виклад основного матеріалу. Сучасна українська педагогічна думка користується визначенням поняття “грамотність", яке подається у словнику С. Гончаренка. Так, під поняттям “грамотність” мається на увазі “ступінь обізнаності з певної галузі знання”. Окрім того, “конкретний зміст цього поняття змінюється на різних етапах економічного й політичного розвитку суспільства разом $з$ підвищенням його культурних запитів" $[1,74]$.

Однією з важливих загальносвітових тенденцій сучасної шкільної освіти є формування життєвих компетентностей, які необхідні для успішної самореалізації у житті, навчанні та праці, визначенні та розв'язанні проблем в певній сфері діяльності людини незалежно від ситуації.

Сьогодні нормативно визначена чітка ієрархія компетентностей:

- надпредметні (ключові) - компетентності, які містять певний комплекс знань, умінь, навичок, ставлень, що набуваються учнями всім змістом шкільної освіти;

- галузеві - компетентності, які набуваються при опануванні змісту певної освітньої галузі в усіх класах середньої школи;

- предметні - компетентності, які формуються впродовж опанування певного навчального предмета в усіх класах середньої школи;
- міжпредметні - компетентності, які прищеплюються певними навчальними предметами й освітніми галузями

3 вересня 2018 р. вступає в дію програма “Нова українська школа. Простір освітніх можливостей”, у якій зазначаються такі ключові компетентності, як: спілкування державною (i рідною у разі відмінності) мовою, спілкування іноземними мовами, математична грамотність, компетентності в природничих науках i технологіях, інформаційно-цифрова компетентність, уміння навчатися впродовж життя, соціальні й громадянські компетентності, підприємливість, загальнокультурна грамотність, екологічна грамотність і здорове життя.

Іншою важливою загальносвітовою тенденцією в сучасній шкільній освіті $€$ інтеграція змісту різних навчальних предметів з метою формування в учнів зв'язків між різними галузями знань, які вивчаються учнями. Підприємницька та фінансова складові у програмах багатьох шкільних предметів міститься у прихованому вигляді. Вчені переконують, що розгляд тем із прихованим на перший погляд, підприємницьким та фінансовим змістом на уроках історії, англійської мови, зарубіжної літератури, математики чи біології допоможе учням побачити предмет із різних боків, відчути багатогранність і неоднозначність світу [6, 34].

Як вважають творці “Нової української школи”, засвоєння інтегрованої змістової лінії “підприємливість і фінансова грамотність" забезпечить краще розуміння молодим поколінням практичних аспектів фінансових питань, пов'язаних зі здійсненням заощаджень, інвестування, запозичення, страхування, кредитування тощо; сприятиме розвиткові лідерських ініціатив, здатності успішно діяти в технологічному швидкозмінному середовищі.

Тобто, шкільний курс “Історія України” є “чудовим майданчиком” у навчанні ключової компетентності “ініціативність” та реалізації інтегрованої змістової лінії “підприємливість та фінансова грамотність”. Спробуємо обгрунтувати та визначити методичні рекомендації, які доцільно використовувати у навчанні “підприємливості та фінансової грамотності” на уроках історії України.

На думку дослідників, розвиток підприємницької компетентності у процесі вивчення історії України в школі відбувається через навчання на трьох рівнях: засвоєння знань про підприємницьку та фінансову діяльність (“навчання про”), розвитку розуміння і ставлення до підприємницької та фінансової діяльності (“навчання для розвитку розуміння та ставлень”), 


\section{МЕТОДИЧНІ РЕКОМЕНДАЦЇ ЩОДОНАВЧАННЯ 'ПІДПРИЄМЛИВОСТІ ТА ФІНАНСОВОЇ ГРАМОТНОСТГ"НА УРОКАХ ІСТОРІЇ УКРАЇНИ}

а також через здобуття практичного досвіду підприємницької чи фінансової діяльності (“навчання через досвід”) [2, 32].

Очевидно, що "навчання про" обумовлене вимогами навчальної програми з історії України. Проте, на думку британських вчених Д. Карсона (D. Carson) та А. Гілмора (A. Gilmore), які у статті "Маркетинг на межі поділу: не “що”, а “як" (Marketing at the Interface; Not "What" but "How") стверджують, що у розвитку ініціативності та креативності вагомим $є$ побудова змісту не навколо ідеї “що”, а навколо ідеї “як”. Тобто, вартий уваги не зміст, а сам процес досягнення успіху чи невдачі конкретними людьми в певний історичний час, якщо мова йде про формування підприємливості.

На думку Є. Бобінської, “екзистенціальний контекст освіти передбачає іiі тісний зв'язок 3 життєвою практикою, придатність знань як у щоденному, так і професійному житті” [6, 38]. Тому, пов'язаність змісту конкретного уроку 3 реальним світом дитини $\epsilon$ важливим інструментом творення підприємницького тла.

К. Кошевська переконана, що окрім знань, базою всіх ключових компетентностей є емоції. Їхня відсутність “найчастіше буває причиною порушень рівноваги у суспільних відносинах між учасниками занять та між вчителем і учнями, вчителем й іншими працівниками школи чи батьками" [6, 29]. На уроках історії України використання змагальності, ігрових моментів, творчого характеру діяльності, пізнавального інтересу тощо сприятиме зростанню активності учнів, наповненню навчального змісту емоціями.

На думку Є. Бобінської, натхненням інтелектуального розвитку учнів у формуванні “підприємливості та фінансової грамотност" постає виклик $[6,38]$. Ці виклики, по-перше, мають бути не надто легкими, але й не дуже складними для конкретної особи, а, по-друге, містити багато можливих варіантів вирішення.

Навчальна програма 3 історії рекомендує використовувати біографії історичних постатей, відомих підприємців-меценатів, які розвивали українську культуру як основні навчальні ресурси у формуванні “ініціативності та підприємливості” $[4,9]$.

Тому, у засвоєнні знань про підприємницьку та фінансову діяльність (“навчання про”) варто дотримуватися таких методичних рекомендацій, як:

- використання можливостей змісту шкільної програми з історії України;

- концентрація уваги на історії успіху чи невдачі конкретних людей у певну історичну епоху;
- проблемний характер змісту та процесу навчання;

- залучення реального світу, можливостей та інтересів учнів до змісту підприємницького та фінансового матеріалу;

- включення емоцій у зміст матеріалу, який використовується у навчанні “підприємливості та фінансової грамотності".

У сучасній методичній науці вагому увагу присвячують розвитку розуміння і ставлення до підприємницької та фінансової діяльності (“навчання для розвитку розуміння та ставлень”). На думку Г. Назаренко, процес набуття підприємницької компетентності має суб'єктивнооб'єктивний характер. Це пояснюється тим, що в кожної людини виробляється власне ставлення до певних економічних реалій, формується власний погляд щодо економічних відносин та їхніх перспектив у майбутньому, висловлюється оцінка власних можливостей в економічній сфері $[5,4]$ Щоб це було втілено, варто добирати навчальний матеріал таким чином, щоб, з одного боку, він був посильним для їхнього віку та навчальних можливостей, a, з іншого боку, щоб на його основі учні могли сформувати власне ставлення до економічних реалій.

Щодо ставлень, які мають бути сформовані під час опанування "підприємливості та фінансової грамотності”, то вони визначені такими як:

- по-перше, “готовність використовувати досвід історії для самопізнання й досягнення добробуту”;

- по-друге, “усвідомлення важливості дотримання етичних норм підприємницької діяльності та потреби розвитку соціально відповідального бізнесу";

- по-третє, “зважений підхід до ухвалення рішень, що несуть ризики, грунтований на досвіді минулого і сучасного соціального життя" $[4,9]$.

Будуючи навчальний процес таким чином, щоб це сприяло напрацюванню ставлень серед учнів щодо підприємливості та ініціативності, методисти відзначають, що без активної участі учителя тут не обійтись.

Дослідник Р. Шиян закликає, що усякі реформи в освіті починати треба з учителя. Саме на вчителеві лежить місія устворенні умов “для того, щоб учень умів учитися, думати, шукати, вдосконалювати, спілкуватися, діяти й співпрацювати в колективі. Організовуючи процес навчання, вчитель визначає тематику, цілі, передбачувані наслідки, способи перевірки й оцінювання досягнень учнів". Якщо говоримо про підприємливість та ініціативність, то 3 позицій К. Кошевської, “моделювання поведінки, формування позицій відбувається через особистий 


\section{МЕТОДИЧНІ РЕКОМЕНДАЦЇ̈ ЩОДОНАВЧАННЯ "ПІДПРИЄМЛИВОСТІ ТА ФІНАНСОВОЇ ГРАМОТНОСТІ"НА УРОКАХ ІСТОРІЇ УКРАЇНИ}

приклад учителя. Тому вчитель мусить вдосконалюватися, працювати над собою, безупинно рефлексувати над власним розвитком”. Натомість, дослідниця М.Товкало переконує, що “можна діяти, якщо ти вмотивований і компетентний учитель, що розуміє, як створити підприємницьке тло на будь-якому уроці через зміст і через форму" [6, 19-39].

Тому, у розвитку розуміння і ставлень до підприємницької та фінансової діяльності на уроках історії України (“навчання для розвитку розуміння та ставлень”), необхідно дотримуватися таких методичних рекомендацій, як:

- побудова змісту навчального матеріалу та процесу навчання таким чином, щоб це сприяло активному напрацюванню особистих ставлень та розумінь учнів аспектів підприємницької та фінансової діяльності;

- врахування бажань та можливостей учителів у створенні належного підприємницького тла через зміст заняття та різні форми навчальної діяльності (індивідуальна, парна, групова, колективна).

Останній аспект, який потребує аналізу, є здобуття практичного досвіду підприємницької та фінансової діяльності на уроках історії України (“навчання через досвід”). У навчальній програмі 2017 р. $з$ історії визначений такий блок умінь, які мають бути сформовані у сучасних школярів, якот:

- використання досвіду пізнання історії для вибору дійових життєвих стратегій;

- виявлення можливостей та загроз для майбутньої професійної та підприємницької діяльності, аналіз світового досвіду та уроків минулого;

- праця для загального добра громади;

- генерування нових ідей, оцінка переваг та ризиків, ведення перемовин, робота як самостійно, так і в групі;

- планування, організація, реалізація індивідуальних чи командних проектів (зокрема дослідницько-пошукового характеру), представлення їх результатів $[4,9]$.

3 одного боку, як вважають А. Довгань та О. Часнікова, саме “звернення до досвіду учнів $\epsilon$ найціннішим матеріалом на уроці”. 3 іншого боку, на думку Г. Назаренко, той необхідний мінімум досвіду, який мають учні в економічній сфері життя людини, має виступати базою у набутті подальших умінь та навичок у підприємницькій та фінансовій діяльності $[3,79 ; 5,38]$. Тобто, використовуючи досвід учнів, можна навчати через дію, створюючи шанси для практичної перевірки знань, розвитку вміння критично мислити та формування активного ставлення до життя.
У методичній науці існує рекомендація, що реалізація “підприємливості та фінансової грамотності” втілюється в навчанні історії України як у теоретичному змісті шкільного курсу, так і під час виконання практичних робіт, розв'язання задач, роботи з різними джерелами інформації' $[3,79 ; 5,38]$.

Дослідниця М. Товкало відзначає, що підприємницьку складову можна розвивати кожного уроку через методи, які спонукатимуть учня бути активним, ініціативним, комунікабельним, відповідальним тощо. Це можливо через використання діяльнісного підходу, суть якого можна передати через т.зв. формулу “90\% практики $+10 \%$ таланту $=100 \%$ успіху” [6, 35]. Тобто, запорукою успіху у навчальній діяльності між теоретичним та практичним змістом перевага має бути на користь практики.

Шкільні реалії засвідчують, що вчителі часто гоняться за теоретичним проходженням тем, нехтуючи розвитком компетентностей учнів. Щоб цьому завадити, вчені пропонують активне використання інтерактивних методів навчання. Застосування цих методів у навчальному процесі сприяє як поглибленню здобутих знань, їх оперативності й стійкості, так і дозволяє змоделювати життєві ситуації на уроках, спонукаючи учнів мислити, спілкуватися та діяти $[6,39 ; 3,79]$.

Залежно від цілей, які ставить вчитель до певного уроку, методистами напрацьована класифікація методів у навчанні “підприємливості та фінансової грамотності” на уроках історії України. Умовно їх можна об'єднати у три групи, а саме:

- методи, що сприяють розвитку вмінь критичного мислення, умовиводів, аналізу, оцінюванню та узагальненню фактів (наприклад, “мозковий штурм”, “ПНЦ”, робота $з$ текстомджерелом тощо).

- методи, що зосереджуються на формуванні відповідальності, проведенні та оцінці вибору, а також прийнятті рішень 3 повним усвідомленням наслідків (наприклад, “дерево прийняття рішень”, метаплан тощо).

- методи, що дозволяють розвивати уяву, роблячи опору на емоції та переживання учнів, заохочують до дії (наприклад, драма, моделювання тощо) [6, 40 - 41].

Тому, навчання через здобуття практичного досвіду підприємницької та фінансової діяльності на уроках історії України (“навчання через досвід”) повинно містити реалізацію таких методичних рекомендацій, як:

- врахування досвіду учнів у побудові навчального матеріалу та змісту уроків; 


\section{МЕТОДИЧНІ РЕКОМЕНДАЦІЇ ЩОДОНАВЧАННЯ “ПІДПРИЄМЛИВОСТІ ТА ФІНАНСОВОЇ ГРАМОТНОСТІ"НА УРОКАХ ІСТОРІЇ УКРАЇНИ}

- активне використання інтерактивних методів
навчання;
- побудова навчального процесу таким чином,
щоб більше часу учні працювали творчо над
вирішенням певної навчальної проблеми;
- реалізація “підприємливості та фінансової
грамотності” як на теоретичному рівні
(наприклад, через відповіді на запитання вчителя,
учнів), так і на практичному рівні (наприклад, через виконання проектів, написання есе тощо).

Висновки. Отож, можемо констатувати, що навчальний предмет “Історія України” $\epsilon$ універсальним та має величезний потенціал у реалізації інтегрованої змістової лінії “підприємливість та фінансова грамотність". Дієвим механізмом втілення цієї лінії $€$ використання компетентнісного, діяльнісного та особистісно орієнтованого підходів. Основні методичні рекомендації є такими, як:

- використання потенціалу змісту навчальної програми з історії України;

- бажано робити акцент на тому, яким чином було досягнуто успіху одними людьми та невдало реалізувався потенціал інших упевний історичний час;

- акцентування у змісті навчання на проблемі, 3 якою учні мають впоратися;

- пов'язаність змісту підприємницького та фінансового матеріалуз реальним світом дитини, з iï інтересами та можливостями; - емоційне забарвлення змісту матеріалу, який залучений у навчання "підприємливості та фінансової грамотності”.

- побудова матеріалу та процесу навчання таким чином, щоб це сприяло активному напрацюванню особистих ставлень та розумінь учнів аспектів підприємницької та фінансової діяльності;

- врахування бажання та можливості учителя у створенні належного підприємницького тла через зміст заняття та різні форми навчальної діяльності;

- врахування досвіду учнів у побудові змісту матеріалу та в процесі навчання;

- активне залучення інтерактивних методів навчання;

- домінування творчого вирішення певної навчальної проблеми учнями за рахунок теоретичного вивчення матеріалу;

- реалізація "підприємливості та фінансової грамотності” як на теоретичному рівні, так і на практичному рівні.

\section{ЛIТЕРАТУРА}

1. Гончаренко С.У. Український педагогічний словник / С.У.Гончаренко. - К. : Либідь, 1997. - 374 с.
2. Громадянська відповідальність: 80 вправ для формування громадянської та соціальної компетентностей під час вивчення різних шкільних предметів. 5-9 клас / М. Рафальська, О. Боярчук, Н. Герасим. - К. Освіта, 2017. - 136 с.

3. Довгань А.І. Реалізація наскрізної змістової лінії “Підприємливість та фінансова грамотність" у навчальних програмах 5-9 класів / А.І.Довгань, О.В. Часнікова // Інформаційно-методичний збірник. -2017. - № 6. - C.79-85.

4. Навчальні програми для загальноосвітніх навчальних закладів України + опис ключових змін. 5-9 класи. - К.: Видавничий дім “Освіта”, 2017. - 88 с.

5. Назаренко Г. А. Формування підприємницької компетентності учнів загальноосвітніх навчальних закладів у відповідності до вимог нових державних стандартів / Г. А. Назаренко. - Черкаси:ЧОІПОПП, 2014. $-68 \mathrm{c}$.

6. Уроки з підприємницьким тлом / За заг. ред. Е. Бобінської, Р. Шияна, М. Товкало. - Варшава: Сова, 2014. $-400 \mathrm{c}$

\section{REFERENCES}

1. Goncharenko, S. U. (1997). Ukrainskyi pedagogichnyi slovnyk [Ukrainian pedagogical dictionary]. Kyiv: Lybid, 374 p. [in Ukrainian].

2. Rafalska, M., Boiarchuk, O. \& Gerasym, N. (Ed.) Gromadianska vidpovidalnist; 80 vprav dlia formuvannia gromadianskoi ta sotsialnoi kompetentnostei pid chas vyvchennia riznych shkilnykh predmetiv. 5-9 klas [Civil responsibility 80 exercises for creating civil and social competences during learning different school subjects. 5-9 forms]. Kyiv: Osvita, 136 p. [in Ukrainian].

3. Dovgan, A. I. \& Chasnikova, O. V. (2017). Realizatsia naskriznoi zmistovoi linii "Pidpruiemlyvist ta finansova gramotnist" u navchalnykh programakh 5-9 klasiv [Realization of integrated meaningful line "initiative and financial literacy" in curriculums of 5-9 forms]. Informative and methodical digest. No. 6, pp. 79-85. [in Ukrainian]

4. Navchalni program dlia zagalnoosvitnikh navchalnykh zakladiv Ukrainy + opys kliuchovykh zmin. 5-9 klasy (2017). [Curriculums for general educational schools of Ukraine + the description of key changes. 5-9 forms]. Kyiv: Osvita, 88 p. [in Ukrainian].

5. Nazarenko, G. A. (2014). Formuvannia pidpryiemnytskoi kompetentnosti uchniv zagalnoosvitnikh navchalnykh zakladiv $u$ vidpovidnosti do vymoh novykh derzhavnykh standartiv [Creating entrepreneurial competence among schoolchildren of general education in accordance with requirements of new state standards]. Cherkasy: ChOIPOPP Publ., 68 p. [in Ukrainian].

6. Bobinska, E., Shyian, R. \& Tovkalo, M. (Ed.) (2014). Uroky $z$ pidpryiemnytskym tlom [Lessons with entrepreneurial background]. Varshava: Sova, 400 p. [in Ukrainian].

Стаття надійшла до редакції 06.08.2018 